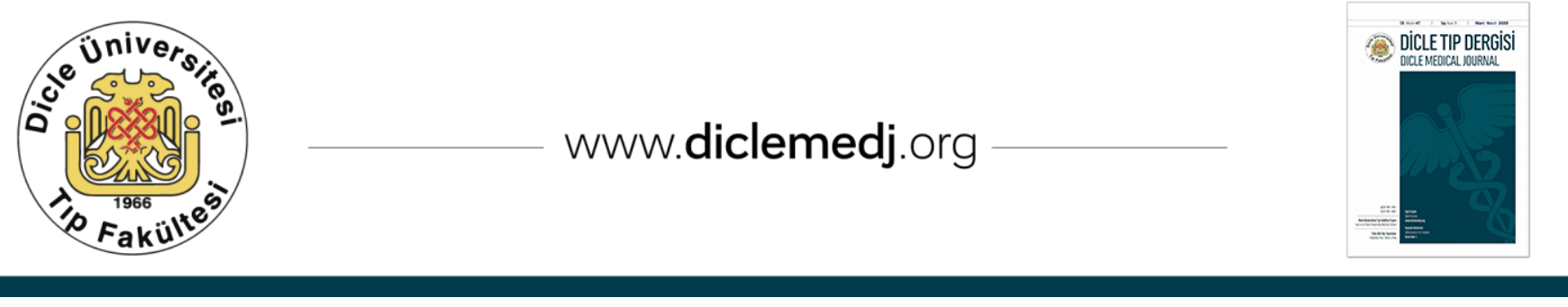

Original Article / Özgün Araştırma

\title{
The Relationship Between Acute Renal Failure After Transcatheter Aortic Valve Replacement And Preprocedural Neutrophil To Lymphocyte Ratio
}

\author{
Nizamettin Selçuk Yelgeç ${ }^{1}$, Mehmet Baran Karataş ${ }^{1}$ iD , Can Yücel Karabay $^{1}$ iD , Yiğit Çanga ${ }^{1}$ iD, Ali Nazmi \\ Çalık $^{1}$ iD Barış Şimşek $^{1}$ iD , Özge Güzelburç ${ }^{1}$ iD Ayşe Emre $^{1}$ iD \\ 1 All Authors are from The Department of Cardiology, Dr. Siyami Ersek Thoracic and Cardiovascular Surgery Training and Research Hospital, İstanbul, \\ Turkey
}

Received: 02.10.2019; Revised: 29.01.2020; Accepted: 11.02.2020

\begin{abstract}
Objective: Transcatheter aortic valve replacement (TAVR) is a less invasive alternative to open-heart surgery for patients with severe symptomatic aortic stenosis who has a high risk for surgery. Acute kidney injury (AKI) is not a rare complication after TAVR and has been associated with poorer outcomes and survival. This study aims to analyze the relation between serum Neutrophil-lymphocyte ratio (NLR) and AKI in Post-TAVR patients.
\end{abstract}

Methods: 148 patients who have been performed TAVR at our institution between 2010 and 2018, analyzed retrospectively. We divided the patients into two groups. Group $1(\mathrm{n}=116)$ : The patients who did not develop AKI after TAVR procedure (control group) and Group $2(\mathrm{n}=32)$ : The patients who developed AKI after TAVR. The independent relation between possible independent predictors of AKI in post-TAVI patients was analyzed by regression analysis.

Results: 32 patients (22\%) suffered from AKI after TAVR during hospitalization. NLR was significantly associated with the development of AKI ( $3.22 \pm 0.62$ vs. $2.42 \pm 0.45$, p<0.01). In multivariate regression analysis, NLR (OR: $1.79, p=0,01)$, diabetes mellitus (OR: 1.41, p=0,01), and preprocedural creatinine levels (OR: 1.86, $\mathrm{p}=0,01$ ) were found to be independently correlated with the development of AKI after TAVR.

Conclusion: This study suggests that High NLR was independently associated with AKI in post-TAVR patients. High values of NLR may indicate a poor prognosis.

Keywords: Neutrophil to lymphocyte ratio, Transcatheter aortic valve implantation, acute renal failure

DOI: 10.5798/dicletip.705532

Correspondence / Yazışma Adresi: Nizamettin Selçuk Yelgeç, Department of Cardiology, Dr. Siyami Ersek Thoracic and Cardiovascular Surgery Training and Research Hospital, 34668 Üsküdar-Istanbul Turkey e-mail: yelgec@gmail.com 


\title{
Transkateter Aort Kapak Replasmanı Sonrası Gelişen Akut Böbrek hasarı ile İşlem Öncesi Nötrofil Lenfosit Oranı Arasındaki İlişki
}

Öz

Giriș: Transkateter aort kapak replasmanı (TAVR), cerrahi aort kapak replasmanına alternatif olarak, ciddi aort stenozu olan yüksekcerrahi riskli hastalar için günümüzde kabul görmüş ve gelişen bir tedavi seçeneğidir. Akut böbrek hasarı (ABH), TAVR sonrası sık görülen bir komplikasyon olup daha kötü sonuçlarla ve sağ kalımla ilişkilidir. Bu çalışmanın amacı TAVR yapılan hastalarda, işlem öncesi serum nötrofil lenfosit oranı (NLR) ile işlem sonrası gelişen ABH arasındaki ilişkiyi araştırmaktır.

\begin{abstract}
Yöntemler: Kurumumuzda 2010- 2018 tarihleri arasında TAVR uygulanan 148 hastanın retrospektif analizi yapılmıştır. Hastalar iki gruba ayrılmıştır. Grup $1(\mathrm{n}=116)$ : TAVR uygulanan ancak ABH gelişmeyen kontrol grubu hastalar; Grup 2 ( $\mathrm{n}=32$ ): TAVR sonrası ABH gelişen hastalar. Veriler akut böbrek hasarının olası bağımsız belirteçlerini tespit etmek için regresyon analizi yöntemi ile analiz edilmiştir.

Bulgular: Bu çalışmada 32 hasta da (\%22) TAVR sonrası ABH gelişmiştir. Nötrofil lenfosit Oranı, ABH gelişimi ile anlamlı olarak ilişkili (3.22 \pm 0.62 vs. $2.42 \pm 0.45$, p<0.01) bulunmuştur. Çok değişkenli regresyon analizinde, NLR (OR: 1.79, p=0,01), diyabetes mellitus (OR: 1.41, p=0,01) ve TAVR öncesi kreatinin düzeyi (OR: 1.86, p=0,01), ABH gelişiminin bağımsız belirteçleri olarak saptanmıştır.
\end{abstract}

Tartışma ve Sonuç: Bu çalışmanın sonuçları, NLR'nin, TAVR sonrası ABH gelişiminin bağımsız bir belirteci olduğunu göstermektedir. Bu bulgulara göre NLR, TAVR sonrası akut böbrek hasarı gelişimi öngörmede pratik ve kullanışlı bir belirteç olabilir. NLR' nin yüksek değerleri kötü prognoza işaret edebilir.

Anahtar kelimeler: Nötrofil-lenfosit oranı, Transkateter aort kapak implantasyonu, Akut böbrek yetmezliği.

\section{INTRODUCTION}

Aortic valve stenosis (AS) is a widespread problem affecting $\% 2$ of the population after 65 years of age and is a frequent cause of left ventricular outflow obstruction in developed countries, and it is the leading indication for surgical valve replacement all around the world ${ }^{1,2}$. Recently transcatheter aortic valve replacement (TAVR) gained popularity among patients with severe AS who have high-surgicalrisk. It became an essential alternative to openheart surgery ${ }^{3}$.

Acute kidney injury (AKI) is a widespread complication seen after TAVR and has been associated with poorer outcomes and survival ${ }^{4}$. Even small decreases in kidney function can result in an increased risk of worse outcomes and mortality. The frequency of AKI was highly dependent on the definition used, and the incidence of AKI after TAVR found to be between 3.4 to $57 \%$ in a recent analysis and was associated with increased hospital length of stay, in-hospital mortality and decreased longterm survival ${ }^{5}$.

The Neutrophil/lymphocyte ratio (NLR) has been gaining increasing attention and popularity across many fields of medicine within the past five years. Currently, there are almost 6.000 publications about this in PubMed, mostly within the past few years. Clinicians use this marker widely to assess physiological stress and prognosis in many situations. NLR gives information about two critical and opposite immune pathways. Neutrophils are responsible for active nonspecific inflammation, and lymphopenia is a marker of poor general health and physiological stress. Thus, NLR is more predictive than either parameter alone. In cardiology, the results of previous studies consistently showed that NLR was a useful marker of adverse cardiovascular events ${ }^{6}$. The relationship between elevated NLR and arterial stiffness, high coronary calcium scores, progression of atherosclerosis, increased incidence of new-onset atrial fibrillation is well 
established and NLR also is an independently associated with mortality in acute coronary syndromes, stable coronary artery disease, cardiac arrhythmias, coronary artery bypass surgery, aortic dissections and in primary percutaneous coronary interventions and heart failure ${ }^{6-13}$

However, our knowledge about the association of NLR with AKI in post-TAVR patients is insufficient. Therefore, in this study, we aimed to investigate the relationship between baseline NLR and the development of AKI in post TAVR patients. Since NLR is non-invasive, widely available, and it can be obtained easily from a simple complete blood count, we studied whether NLR and other hematological parameters can serve as potential markers to predict the outcome of patients undergoing TAVR.

\section{METHODS}

We screened medical records of all consecutive patients who had undergone transfemoral TAVR between the years 2010 and 2018 at our institution. Data about clinical and demographic variables and laboratory parameters were obtained from medical records. Patients who had been receiving dialysis for a long time and patients who had a new kidney transplant within 14 days were excluded from the study. Patients with acute or chronic infection, life-threatening cardiac and non-cardiac problems, active hematologic diseases, collagen vascular disease, or malignancy were also excluded. Finally, we included 148 patients who underwent successful TAVR in the study. All patients signed and dated the informed consent for the procedure. The local research and ethics committee approved the study protocol, and the study was conducted following the ethical principles described by the Declaration of Helsinki.

\section{Definition Of NLR And Other Hematological Parameters}

In our center, complete blood counts with automated serum neutrophil and lymphocyte differentials were calculated with Coulter LH 780 Hematology Analyzer device. We calculated NLR by dividing the absolute neutrophil count by absolute lymphocyte count.

\section{Definition of AKI after TAVR}

The Valve Academic Research Consortium (VARC-2), in their second updated consensus report, recommended acute kidney injury network (AKIN) criteria for defining and staging acute kidney injury regarding the TAVR procedure (14). A minimum of $0,3 \mathrm{mg} / \mathrm{dL}$ or 1.5 fold increase in the serum creatinine within seven days after TAVR is required for the definition of AKI. The decline in kidney function should occur within 48 hours. The patients with acute renal failure staged into three groups depending on the severity of renal deterioration (Table 1). In our study, patients in all three stages of AKIN criteria were classified into one group as post-TAVR renal failure.

\section{Procedure and Postprocedural Care}

Preprocedural assessment for patients with symptomatic, severe AS who was a candidate for TAVR, included routine clinical preoperative tests, left-heart catheterization, transthoracic and transesophageal echocardiography, CTangiography and if necessary, some other consultations. The test results analyzed by the expert TAVR Heart Team to determine if the patient is a suitable candidate for TAVR. The patients should have life expectancy $>1$ year, and the traditional open surgery alternative should not be appropriate due to high surgical risk. Logistic European System for Cardiac Operative Risk Evaluation Score (EuroSCORE) was used to evaluate the risk of surgery ${ }^{15}$. 
Table I: AKIN criteria for Acute Renal Failure

\begin{tabular}{|c|c|c|}
\hline Stage & Serum Creatinine & $\begin{array}{l}\text { Urine Output } \\
\text { Criteria }\end{array}$ \\
\hline & $\begin{array}{l}\text { Creatinine increase 1.5-1.9-fold from } \\
\text { baseline }\end{array}$ & \\
\hline 1 & $\begin{array}{l}\text { OR } \\
\text { Creatinine increased by at least } 26.5 \\
\mu \mathrm{mol} / \mathrm{L}(\geq 0,3 \mathrm{mg} / \mathrm{dl})\end{array}$ & $\begin{array}{l}\text { Urine output }(\mathrm{U} / 0)< \\
0.5 \mathrm{ml} / \mathrm{kg} / \mathrm{h} \text { for } 6-12 \\
\text { hours }\end{array}$ \\
\hline 2 & $\begin{array}{l}\text { Creatinine increase } 2.0-2.9 \text {-fold (i.e. } \\
\text { doubled or tripled creatinine) }\end{array}$ & $\begin{array}{l}\mathrm{U} / 0<0.5 \mathrm{ml} / \mathrm{kg} / \mathrm{h} \text { for } \\
12-24 \text { hours }\end{array}$ \\
\hline 3 & $\begin{array}{l}\text { Creatinine increase }>3.0 \text {-fold } \\
\text { Alternatively, } \\
\text { A creatinine over } 354 \mu \mathrm{mol} / \mathrm{L}(4 \\
\mathrm{mg} / \mathrm{dl}) \text {, with an acute increase by at } \\
\text { least } 44 \mu \mathrm{mol} / \mathrm{L}(0.5 \mathrm{mg} / \mathrm{dl}) \\
\text { OR } \\
\text { The initiation of renal replacement } \\
\text { therapy }\end{array}$ & $\begin{array}{l}\mathrm{U} / 0<0.3 \mathrm{ml} / \mathrm{kg} / \mathrm{h} \text { for } \\
>=24 \text { hours } \\
\text { Alternatively, } \\
\text { Anuria for } 12 \text { hours }\end{array}$ \\
\hline
\end{tabular}

An experienced team performed all procedures. TAVR was performed using all available selfexpandable and balloon-expandable prosthesis. All patients were monitored postoperatively in the intensive care unit for at least 24-48 hours after valve implantation. Standard dual antiplatelet therapy was given for a median duration of 3-6 months. Aspirin was continued for life. Patients using oral anticoagulants stopped aspirin and clopidogrel after one month.

The volume of iodinated contrast medium used during the TAVR procedures was about between 100-150 ml depending on the valve type. Generally, TAVR with balloon-expandable valves required more iodinated contrast media.

\section{Statistical Analysis}

We used Statistical Package for Social Sciences software version 16 (SPSS 16.0 for Windows, SPSS Inc., Chicago, Illinois) to analyze the data. Mean values are expressed as mean \pm SD, and categorical variables expressed as percentages for descriptive statistic purposes. We examined continuous variables by using KolmogorovSmirnov statistics to understand if the distribution was normal. For inferential statistics, we used the student t-test, MannWhitney U test, Pearson's $\chi 2$ test or Fisher's Exact Test depending on necessity. Logistic regression models analyzed the effects of covariates on AKI. To find out the independent predictors of mortality and to see the impact of variables more clearly, we used forward stepwise multivariate regression models and included only parameters with $\mathrm{p}<0.10$. P values $<0.05$ were considered statistically significant. Finally, receiver operating curves (ROC) were drawn and analyzed to define cut-off values for NLR values.

\section{RESULTS}

In our study population, Out of 148 suitable patients ( $45 \%$ male; mean age $79 \pm 7.3$ years) who underwent TAVI, 32 patients (\% 21.6) developed AKI within seven days after the procedure, and 11 patients (7\%) died within 30 days. Clinical, demographic, and laboratory characteristics of patients with AKI and those without are summarized in Tables 2 and 3.

When subjects with AKI were compared to those without, the AKI group had a more advanced age than AKI (-) group (81.8 7.8 vs. $79 \pm 6.9$ $\mathrm{p}=0.047)$. There were no significant differences in terms of ejection fraction (EF), aortic valve area (AVA), Hypertension (HT), coronary artery disease (CAD), peripheric arterial disease (PAD), and gender between groups. Laboratory and clinical data showed that in AKI (+) group, the NLR was significantly higher compared to those patients without AKI (3.22 \pm 0.62 vs. $2.42 \pm 0.45$, p <0.01). Serum creatinine, logistic EuroSCORE, Red cell distribution width (RDW), and the frequency of diabetes mellitus (DM) were significantly higher in patients who developed AKI. However, absolute lymphocyte count was significantly lower in AKI (+) group (Table III). 
Table II: Demographic and Clinical characteristics of the study population $(\mathrm{n}=148)$

\begin{tabular}{|l|l|l|l|}
\hline & AKI (-) & AKI (+) & P-value \\
\hline Age, years & $79 \pm 6.9$ & $81.8 \pm 7.8$ & $\mathbf{0 . 0 4 7}$ \\
\hline Male gender, n (\%) & $52(45)$ & $15(47)$ & 0.83 \\
\hline Hypertension, n (\%) & $98(85)$ & $24(76)$ & 0.21 \\
\hline Diabetes mellitus, n (\%) & $41(35)$ & $21(66)$ & $\mathbf{0 . 0 1}$ \\
\hline CAD, n (\%) & $65(56)$ & $18(57)$ & 0.98 \\
\hline CHF, n (\%) & $11(7)$ & $4(13)$ & 0.56 \\
\hline PAD, n (\%) & $31(26.7)$ & $6(19)$ & 0.35 \\
\hline Logistic EuroSCORE & $20.6 \pm 4.2$ & $22.4 \pm 5.4$ & 0.04 \\
\hline AVA, (cm $\left.{ }^{2}\right)$ & $0.74 \pm 0.16$ & $0.69 \pm 0.13$ & 0.10 \\
\hline EF, (\%) & $52,5 \pm 7.8$ & $53.2 \pm 8.5$ & 0.65 \\
\hline Mortality, n (\%) & $6(5)$ & $5(15)$ & 0.06 \\
\hline
\end{tabular}

Notes. CAD: coronary artery disease, CHF: congestive heart failure; PAD: Peripheric arterial disease, AVA: Aortic valve area, EF: Ejection fraction

Bolded values indicate statistical significance $(p<0.05)$

Table III. Comparison of laboratory parameters in the study population

\begin{tabular}{|c|c|c|c|}
\hline & AKI (-) & AKI (+) & \multirow{2}{*}{$\begin{array}{l}\text { P- } \\
\text { value }\end{array}$} \\
\hline & $(\mathrm{N}=116)$ & $(\mathrm{N}=32)$ & \\
\hline $\begin{array}{l}\text { Baseline } \\
\text { Creatinine (mg/dL) }\end{array}$ & $1.1 \pm 0.15$ & $1.24 \pm 0.18$ & 0.01 \\
\hline Hemoglobin (mg/dL) & $12.3 \pm 2.32$ & $11.9 \pm 1.73$ & 0.36 \\
\hline Platelet $\left(10^{3} / \mu \mathrm{L}\right)$ & $194 \pm 36$ & $204 \pm 42$ & 0.39 \\
\hline $\begin{array}{l}\text { Mean platelet volume, } \\
\text { (fL) }\end{array}$ & $8.4 \pm 1.2$ & $8.5 \pm 1.1$ & 0.51 \\
\hline $\begin{array}{l}\text { White blood cell count } \\
\left(10^{3} / \mu \mathrm{L}\right)\end{array}$ & $8.7 \pm 1.7$ & $9.1 \pm 1.8$ & 0.25 \\
\hline $\begin{array}{l}\text { Neutrophil } \\
\left(10^{3} / \mu \mathrm{L}\right)\end{array}$ & $5.72 \pm 1.26$ & $5.94 \pm 1.43$ & 0.39 \\
\hline Lymphocyte $\left(10^{3} / \mu \mathrm{L}\right)$ & $2.2 \pm 0.54$ & $1.62 \pm 0.38$ & 0.01 \\
\hline $\begin{array}{l}\text { Red cell distribution } \\
\text { width }\end{array}$ & $14.3 \pm 1.92$ & $15.2 \pm 1.85$ & 0.02 \\
\hline NLR & $2.42 \pm 0.45$ & $3.22 \pm 0.62$ & 0.01 \\
\hline
\end{tabular}

Notes. NLR - neutrophil/lymphocyte ratio

Bolded values indicate statistical significance $(p<0.05)$
In univariate logistic regression analysis, RDW, DM, logistic EuroSCORE, NLR, and preprocedural serum creatinine levels were possible independent predictors of AKI in postTAVR patients in the study population. The multivariate model was adjusted for NLR, DM, Logistic EuroSCORE, and serum creatinine levels. In multivariate logistic regression analysis, NLR (OR: 1.79 95\% CI: 1.28-4.48, p < 0.01), DM (OR: 1.41 95\% CI: 1.12-2.28, $\mathrm{p}=0.01$ ), and serum creatinine levels (OR: 1.86 95\% CI: 1.11-4.66, $\mathrm{p}=0.01$ ) remained independent predictor of AKI development in the study population (Table IV).

Table IV: Multivariate regression analysis of possible predictors of AKI in the study population

\begin{tabular}{lcc} 
Variable & p-value & Odds ratio $(95 \% \mathrm{CI})$ \\
\hline RDW & 0.11 & $1.13(0.92-1.38)$ \\
\hline Diabetes Mellitus & $\mathbf{0 . 0 1}$ & $1.41(1.12-2.28)$ \\
& & \\
\hline Logistic EuroSCORE & 0.26 & $1.08(0.92-2.16)$ \\
NLR & $\mathbf{0 . 0 1}$ & $1.79(1.28-4.48)$ \\
Creatinine & $\mathbf{0 . 0 1}$ & $1.86(1.11-4.66)$
\end{tabular}

Notes. RDW red cell distribution width; NLR Neutrophil to Lymphocyte Ratio

Bolded values indicate statistically significant odds ratio.

In ROC curve analysis, the NLR level cutoff point of more than 2.6 predicted the patients with high preprocedural risk for AKI with a sensitivity of $68 \%$ and a specificity of $56 \%$ (area under the curve $=0.655, \mathrm{p}<0.01$ ) (Figure 1 ). Serum creatinine levels over $2.1 \mathrm{mg} / \mathrm{dl}$ predicted AKI with a sensitivity of $90,62 \%$ and a specificity of $43.10 \%$ (AUC $0,632, p<0.01$ ), and presence of DM predicted AKI with a sensitivity of $65,62 \%$ and a specificity of 64.66 $\%$ (AUC $0,651, \mathrm{p}<0.01$ ). When ROC curves were compared, there was no statistical difference between AUC curves of NLR, DM, and serum creatinine levels. 


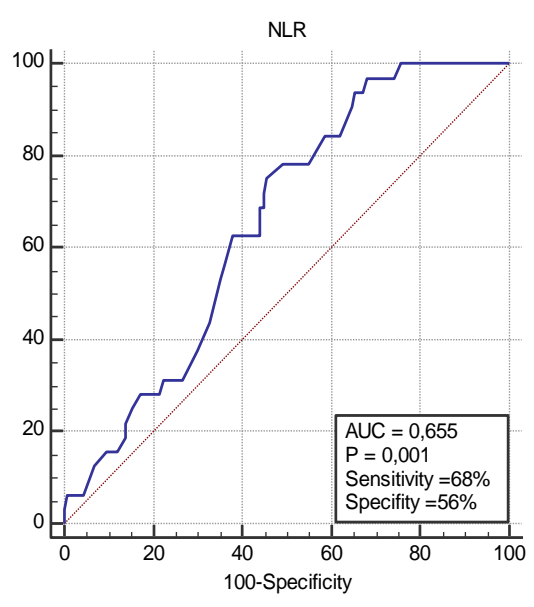

Figure 1: The receiver-operating characteristic curve of NLR

England over a 20-year period. Within this time, there was a significant increase in Finland and Norway compared to other countries and they reported that within these four countries, reference numbers increased in percentages within the last 20 years.

The first limitation of our study is that we used the WOS as search engine. It is known that different databases may display differences in citation numbers. Though additional citation numbers and mean annual citation numbers are traditional parameters to determine the scientific value of an article, the contribution of a study to science cannot be assessed using these parameters alone.

In conclusion, bibliographic articles created using scientific search engines illustrate the topics that researchers focus on. For healthy data analysis, it is recommended that these types of studies should be updated and rewritten at certain intervals.

\section{DISCUSSION}

In this study, we aimed to understand if NLR could be a predictor of AKI in patients who underwent TAVR. We showed that age, creatinine levels, logistic EuroSCORE, RDW, and the frequency of DM were significantly higher in patients who developed AKI. We also found that NLR, DM, and preprocedural creatinine levels were independent predictors of acute injury to kidneys and renal function loss. The primary value of our study is that this is the first to examine the association between NLR and AKI after TAVR procedure, confirming the impact of inflammation in this setting. Since NLR is a measure of subclinical systemic inflammation, it might stratify patients who will benefit less likely from TAVR.

TAVR procedures have internal risks that predispose patients for acute renal failure. TAVR technique needs real-time $x$-ray (cine) and angiographic recording using contrast media to visualize anatomy and to locate the artificial valve correctly. The administration of radiocontrast media may lead to acute contrastinduced nephropathy. Additionally, rapid pacing is necessary to induce cardiac standstill for valve implantation that might cause short periods of extreme hypotension during the procedure and increases the incidence of AKI after TAVR 5 .

Many studies have been conducted to prove the value of NLR in various conditions such as cardiac disorders ${ }^{16-18}$, malignancies ${ }^{19}$, acute renal failure ${ }^{20}$. Studies have also revealed the significant role of inflammation in the pathogenesis of $\mathrm{AKI}^{21}$. Recently, in a large-scale and population-based research, a serious relationship was detected between NLR ratio and HT. Subclinical inflammation in the vessel wall contributed to the pathophysiology of $\mathrm{HT}^{22}$. NLR ratio was found to be higher among older people in this study. Studies showed a close relationship between NLR ratio and age. Most likely, the increased inflammation with advanced age has caused these findings ${ }^{23}$. Consistent with these research findings, our study showed a relationship between acute renal insufficiency and old age. However, in regression analysis age was not an independent predictor of AKI.

High NLR before TAVR might suggest the presence of underlying low degree subclinical 
vascular inflammation (24). Use of guidewires and large catheters in the aortoiliac arteries of patients with advanced atherosclerosis with unstable fragile plaques due to subclinical inflammation might result in micro and macro embolization to renal arteries. Besides, subclinical vascular inflammation might also increase susceptibility to contrast-induced nephropathy ${ }^{25}$. Additionally, the presence of low-grade vascular inflammation might increase renal parenchymal susceptibility to AKI during hypotensive episodes in the TAVR procedure. Recently prosthetic valve thrombosis became a matter of attention in patients that had undergone TAVR due to an article emphasizing the relationship between NLR and prosthetic valve thrombosis ${ }^{26}$. Unnoticed valve thrombosis in post-TAVR patients might reduce blood flow to renal parenchyma due to the reduction in cardiac output and aortic pressure.

Previous studies have identified additional critical predictive factors for AKI after TAVR, such as pre-existing chronic kidney disease, congestive heart failure, need for circulatory support, advanced age, DM, periprocedural blood transfusion, peripheral artery disease and a prior coronary artery bypass grafting27. In our study, DM and preprocedural creatinine levels were significantly associated with AKI development after TAVR. According to our research, in patients with high NLR with additional risk factors, close follow-up in terms of the development of acute renal failure, especially within seven days after TAVR, is reasonable.

\section{CONCLUSION}

Before interpreting these results, some restrictions need to be emphasized. This study is a small-scale, retrospective study. However, to conclude, regarding $\mathrm{CBC}$ parameters, an elevated preprocedural NLR level may be associated with early post-procedural acute renal failure in TAVR patients. Our findings call for further prospective and multicenter studies with a larger sample size to elucidate the prognostic/diagnostic utility of NLR in predicting TAVR related acute renal failure. More research is also needed to understand if aggressive treatment of age-associated diseases before TAVR could lower baseline NLR and will give better results; moreover, if improvements of the TAVR technique and shortening of the duration of operation might decrease inflammatory response and could result in better outcomes.

\section{FUNDING}

The author declares that he received no financial support; there is no conflict of interest for authorship, and publication of this research.

Ethics Committee Approval: The local research and ethics committee approved the study protocol, and the study was conducted following the ethical principles described by the Declaration of Helsinki.

Declaration of Conflicting Interests: The authors declare that they have no conflict of interest.

Financial Disclosure: No financial support was received.

\section{REFERENCES}

1. Lindman BR, Clavel M-A, Mathieu P, et al. Calcific aortic stenosis. Nat Rev Dis Prim. 2016; 2: 16006.

2. Eveborn GW, Schirmer H, Heggelund G, et al. The evolving epidemiology of valvular aortic stenosis. the Tromsø Study. Heart. 2013 Mar 15; 99: 396-400.

3. Nishimura RA, Otto CM, Bonow R0, et al. 2014 AHA/ACC guideline for the management of patients with valvular heart disease: a report of the American College of Cardiology/American Heart Association Task Force on Practice 
Guidelines. J Am Coll Cardiol. 2014 Jun 10; 63: e57-185.

4. Bagur R, Webb JG, Nietlispach F, et al. Acute kidney injury following transcatheter aortic valve implantation: predictive factors, prognostic value, and comparison with surgical aortic valve replacement. Eur Heart J. 2010 Apr 1; 31: 865-74.

5. Najjar M, Salna M, George I. Acute kidney injury after aortic valve replacement: Incidence, risk factors and outcomes. Expert Review of Cardiovascular Therapy. 2015.

6. Papa A, Emdin M, Passino C, et al. Predictive value of elevated neutrophil-lymphocyte ratio on cardiac mortality in patients with stable coronary artery disease. Clin Chim Acta. 2008 Sep; 395: 27-31.

7. Park B-J, Shim J-Y, Lee H-R, et al. Relationship of neutrophil-lymphocyte ratio with arterial stiffness and coronary calcium score. Clin Chim Acta. 2011 May 12; 412: 925-9.

8. Zazula AD, Précoma-Neto D, Gomes AM, et al. An assessment of neutrophils/lymphocytes ratio in patients suspected of acute coronary syndrome. Arq Bras Cardiol. 2008 Jan; 90: 31-6.

9. Duffy BK, Gurm HS, Rajagopal V, et al. Usefulness of an Elevated Neutrophil to Lymphocyte Ratio in Predicting Long-Term Mortality After Percutaneous Coronary Intervention. Am J Cardiol. 2006 Apr 1; 97: 9936.

10. Gibson PH, Cuthbertson BH, Croal BL, et al. Usefulness of Neutrophil/Lymphocyte Ratio As Predictor of New-Onset Atrial Fibrillation After Coronary Artery Bypass Grafting. Am J Cardiol. 2010 Jan 15; 105: 186-91.

11. Rudiger A, Burckhardt OA, Harpes $P$, et al. The relative lymphocyte count on hospital admission is a risk factor for long-term mortality in patients with acute heart failure. Am J Emerg Med. 2006 Jul; 24: 451-4.

12. Gibson PH, Croal BL, Cuthbertson BH, et al. Preoperative neutrophil-lymphocyte ratio and outcome from coronary artery bypass grafting. Am Heart J. 2007 Nov; 154: 995-1002.

13. Bhat T, Teli S, Rijal J, et al. Neutrophil to lymphocyte ratio and cardiovascular diseases: a review. Expert Rev Cardiovasc Ther. 2013 Jan 10; $11: 55-9$.

14. Kappetein AP, Head SJ, Généreux $P$, et al. Updated standardized endpoint definitions for transcatheter aortic valve implantation: the Valve Academic Research Consortium-2 consensus document†. Eur Heart J. 2012 Oct; 33: 2403-18.

15. Roques F, Michel P, Goldstone AR, et al. The logistic EuroSCORE. Eur Heart J. 2003 May 1; 24: 882-3.

16. Park JJ, Jang HJ, Oh IY, et al. Prognostic value of neutrophil to lymphocyte ratio in patients presenting with ST-elevation myocardial infarction undergoing primary percutaneous coronary intervention. Am J Cardiol. 2013;

17. Bhat T, Teli S, Rijal J, et al. Neutrophil to lymphocyte ratio and cardiovascular diseases: A review. Expert Review of Cardiovascular Therapy. 2013.

18. Onuk T, Güngör B, Karataş B, et al. Increased neutrophil to lymphocyte ratio is associated with in-hospital mortality in patients with aortic dissection. Clin Lab. 2015; 61.

19. Yin Y, Wang J, Wang X, et al. Prognostic value of the neutrophil to lymphocyte ratio in lung cancer: A meta-analysis. Clinics. 2015;

20. Turkmen K, Guney I, Yerlikaya FH, et al. The relationship between neutrophil-to-lymphocyte 
ratio and inflammation in end-stage renal disease patients. Ren Fail. 2012; 34: 155-9.

21. Erdem E. Neutrophil lymphocyte ratio in aute renal failure. Indian J Nephrol. 2015; 25: 126-7.

22. Mozos I, Malainer C, Horbańczuk J, et al. Inflammatory Markers for Arterial Stiffness in Cardiovascular Diseases. Front Immunol. 2017 Aug 31; 8: 1058.

23. Li J, Chen Q, Luo X, et al. Neutrophil-toLymphocyte Ratio Positively Correlates to Age in Healthy Population. J Clin Lab Anal. 2015 Nov; 29: 437-43.

24. Nam S-H, Kang S-G, Song S-W. The Neutrophil-Lymphocyte Ratio Is Associated with Coronary Artery Calcification in Asymptomatic
Korean Males: A Cross-Sectional Study. Biomed Res Int. 2017 Feb 9; 2017: 1-8.

25. Candela P, Evola S, Lunetta $M$, et al. The spectrum of risk factors for contrast induced nephropathy in patients undergoing coronary angiography or intervention. J Indian Coll Cardiol. 2014 Sep 1; 4: 157-61.

26. Gürsoy OM, Karakoyun S, Kalçık M, et al. Usefulness of Novel Hematologic Inflammatory Parameters to Predict Prosthetic Mitral Valve Thrombosis. Am J Cardiol. 2014 Mar; 113: 8604.

27. Ram P, Mezue K, Pressman G, et al. Acute kidney injury post-transcatheter aortic valve replacement. Clin Cardiol. 2017 Dec 1; 40: 135762. 